\title{
The Pyrenean architecture as revealed by teleseismic $P$-to- $S$ converted waves recorded along two dense transects
}

\author{
Sébastien Chevrot, ${ }^{1,2}$ Matthieu Sylvander, ${ }^{1}$ Jordi Diaz, ${ }^{3}$ Mario Ruiz, ${ }^{3}$ Anne Paul ${ }^{4}$ \\ and the PYROPE Working Group* \\ ${ }^{1}$ Observatoire Midi Pyrénées, Université Paul Sabatier, Toulouse, France.E-mail: sebastien.chevrot@irap.omp.eu \\ ${ }^{2}$ CNRS, IRAP, UMR 5277 \\ ${ }^{3}$ Institute of Earth Sciences Jaume Almeria, ICTJA-CSIC, Lluis Sole i Sabaris, Barcelona, Spain \\ ${ }^{4}$ Université Grenoble-Alpes, CNRS, ISTerre, Grenoble, France
}

Accepted 2014 October 13. Received 2014 October 10; in original form 2014 July 7

\begin{abstract}
S UMMAR Y
Between 2011 and 2013, two dense transects were deployed across the central and western Pyrenees to get better constraints on the deep lithospheric architecture and discriminate the competing models of the structure and formation of the Pyrenees. Each transect recorded the regional and global seismicity during a period of approximately 1 yr. Here, we exploit the records of teleseismic compressional waves and of their conversions to shear waves on internal discontinuities in order to map lithospheric interfaces beneath the two transects. The migrated sections, obtained by performing common conversion point stacks, are in remarkable agreement with the results of the ECORS-Pyrenees and ECORS-Arzacq deep seismic surveys. However, the migrations of converted waves reveal new details of the deep lithospheric architecture that could not be seen with the active source experiments. The new images provide clear and definite evidence for the subduction of a thinned Iberian crust down to at least $\sim 70 \mathrm{~km}$ depth, a result that has important implications for the formation of the Pyrenees. The subduction of the Iberian lithosphere leads to reconsider the amount of convergence between Iberia and Europe during the Cenozoic. A recent regional $P$-wave tomography, relying on the data of the PYROPE and IBERARRAY temporary experiments, revealed the segmentation of lithospheric structures by inherited Hercynian NE-SW transfer faults that were reactivated during the Albian rifting. Our migration images are consistent with this model, and give further support to the idea that the Pyrenees were produced by the tectonic inversion of a segmented hyperextended rift that was buried by subduction beneath the European Plate.
\end{abstract}

Key words: Seismic tomography; Continental tectonics: compressional; Dynamics of lithosphere and mantle.

\section{INTRODUCTION}

The Pyrenean orogen is a continental collision zone produced by the convergence between Iberia and Eurasia during the Cenozoic. It is an east-west, bivergent orogen flanked by two foreland basins, the Ebro Basin in the south and the Aquitanian Basin in the north (Fig. 1). These foreland basins developed in response to the flexure of the Iberian and European plates during the Pyrenean orogeny (e.g. Brunet 1986).

The deep structure of the Pyrenees has been constrained by a number of active source seismic experiments. Early seismic refrac-

\footnotetext{
* G. Cougoulat, C. Péquegnat, D. Wolyniec, P. Delmas, F. Grimaud, S. Benahmed, H. Pauchet, M. de Saint Blanquat, Y. Lagabrielle, and G. Manatschal.
}

tion surveys relied on two east-west profiles deployed in the Axial Zone and in the North Pyrenean Zone (Explosion Seismology Group Pyrenees 1980). They evidenced a crustal root beneath the Axial Zone, in the central and western Pyrenees, limited to the north by a sharp Moho jump, which approximately coincides with the surface trace of the North Pyrenenan Fault (NPF; Gallart et al. 1981; Daignières et al. 1981, 1982). This striking coincidence gave some support to the interpretation of the NPF as a former vertical plate boundary, along which a sinistral strike-slip movement of about $400 \mathrm{~km}$ occurred during the Albian (e.g. Olivet 1996). This leftlateral displacement was interpreted to be at the origin of pull-apart basins that developed along the NPF during the lower Cretaceous (Choukroune \& Mattauer 1978). The thick crustal root beneath the axial zone also provides an explanation for the pronounced negative Bouguer anomaly observed along most of the Pyrenean range, except in its eastern termination close to the Mediterranean Sea 


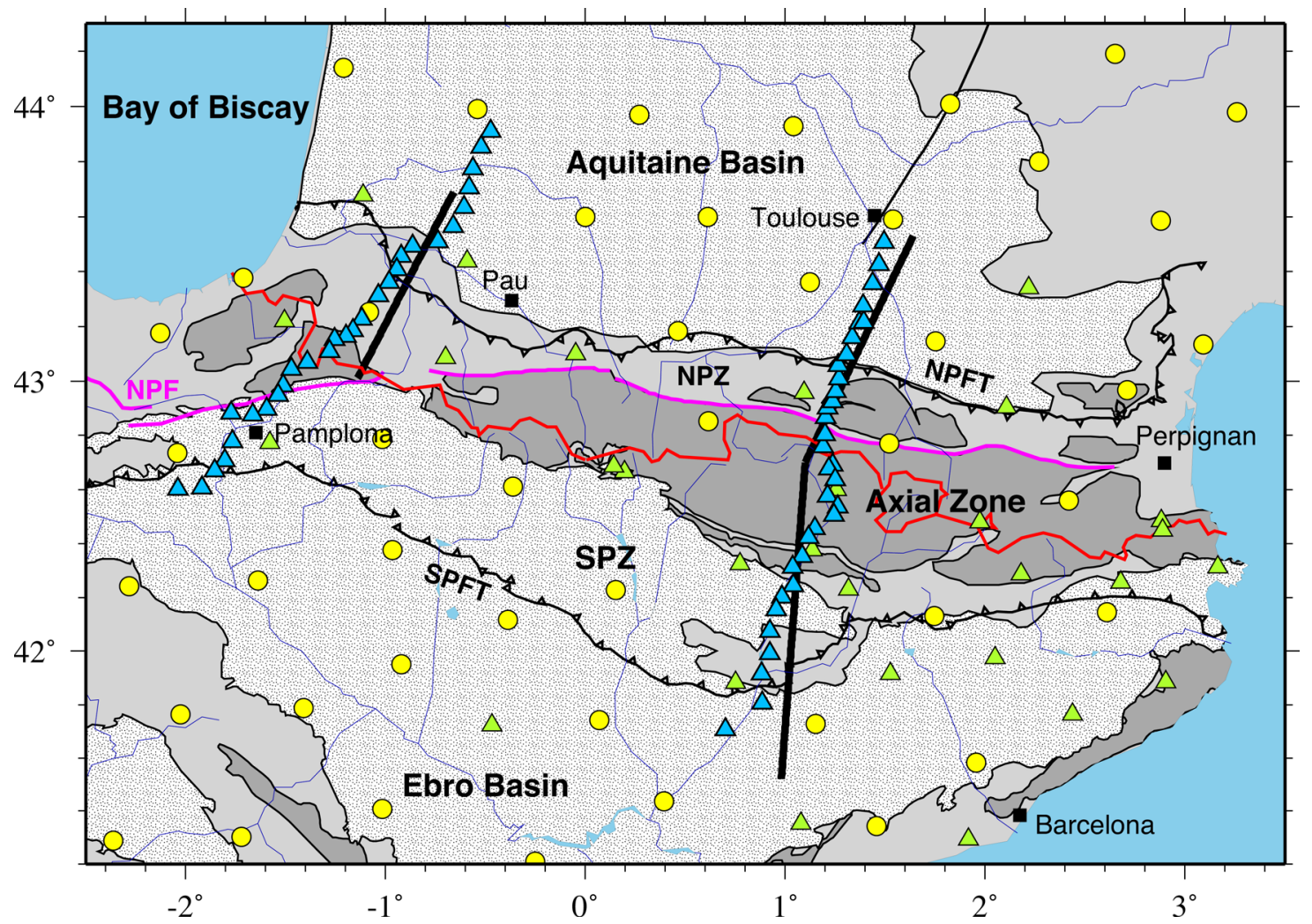

Figure 1. Map of the seismological stations in the study region. The temporary stations deployed along the two dense transects (blue triangles) were complemented by the permanent broad-band stations (green triangles) and by the temporary IBERARRAY and PYROPE stations (yellow circles) located within $10 \mathrm{~km}$ of the transects. The thick black lines show the locations of the central ECORS Pyrenees and western ECORS Arzacq profiles. NPF, North Pyrenean Fault (pink solid line); NPFT, North Pyrenean Front Thrust; SPFT, South Pyrenean Front Thrust; NPZ, North Pyrenean Zone; SPZ, South Pyrenean Zone

(Daignières et al. 1982). The Labourd and Saint Gaudens positive anomalies have been attributed to the presence of dense materials at shallow levels (Daignières et al. 1989), but their exact nature and geometry are still uncertain (Torné et al. 1989; Casas et al. 1997; Vacher \& Souriau 2001).

Despite these important results to be credited to these pioneering studies, many aspects of the Pyrenean architecture remained uncertain and controversial. For example, the structures in the shallow upper crust or the geometry of the main seismic interfaces such as the Moho, which represents a key marker to reconstruct the preorogenic state of the belt and to estimate the amount of convergence, were poorly constrained. This motivated a new deep seismic survey program across the central Pyrenees. In 1985 and 1986, a 250-kmlong profile was shot across the Pyrenees (ECORS Pyrenees Team 1988). At that time, it was the first deep reflection profile to cross an entire orogenic belt. Well-defined reflectors in the upper crust confirmed the general fan shape geometry of the belt (Choukroune $\&$ the ECORS team 1989). In the section, both the Iberian and European lower crusts appear strongly layered, with a succession of north and south-dipping reflectors that have been interpreted as Hercynian thrusts (Choukroune et al. 1990). The Iberian Moho deepens gently towards the north beneath the axial zone, and connects to deep reflectors that plunge beneath the European crust. A wideangle experiment coincident with the vertical reflection line was also carried as part of the ECORS project. The unusual response of the lower crust showed localized and discontinuous north-dipping impedance contrasts (Suriñach et al. 1993).
An attempt to construct a balanced cross-section of the Pyrenees along the ECORS-Pyrenees profile evidenced a large discrepancy between the top of the Iberian Palaeozoic basement and the lower crust (Roure et al. 1989). Depending on the autochthonous or allochthonous nature of the Iberian foreland, the amount of shortening was estimated to be comprised between 50 and $165 \mathrm{~km}$ (Muñoz 1992; Roure \& Choukroune 1998; Beaumont et al. 2000). Different locations have been proposed for the missing Iberian lower crust. In a first hypothesis, the lower crust is subducted beneath the European Plate (Muñoz 1992). Gravity modelling and wide-angle seismic experiments (Daignières et al. 1989) seem to preclude a northern extension of the Iberian crust beneath the NPZ (Roure et al. 1989; Roure \& Choukroune 1998). However, the light subducted crustal material may have been eclogitized, and thus possess density and seismic velocities close to that of the mantle, making its detection by geophysical probes very difficult (Roure \& Choukroune 1998). A second hypothesis is that the missing Iberian lower crust is stacked beneath the axial zone, producing the thick crustal root evidenced by seismic experiments (Roure et al. 1989). In this model, the sharp Moho step beneath the NPF is considered as a strong evidence that the NPF was a subvertical transform plate boundary during the Cretaceous. This fault was truncated and transported passively to the north by the north Pyrenean thrusts during the convergence phase between Iberia and Europe. Schematic crosssections corresponding to these two models are shown in Fig. 2.

In 1989, a second 100-km-long profile was shot in the western Pyrenees (Fig. 1), from the Mendibelza Massif to the south to 

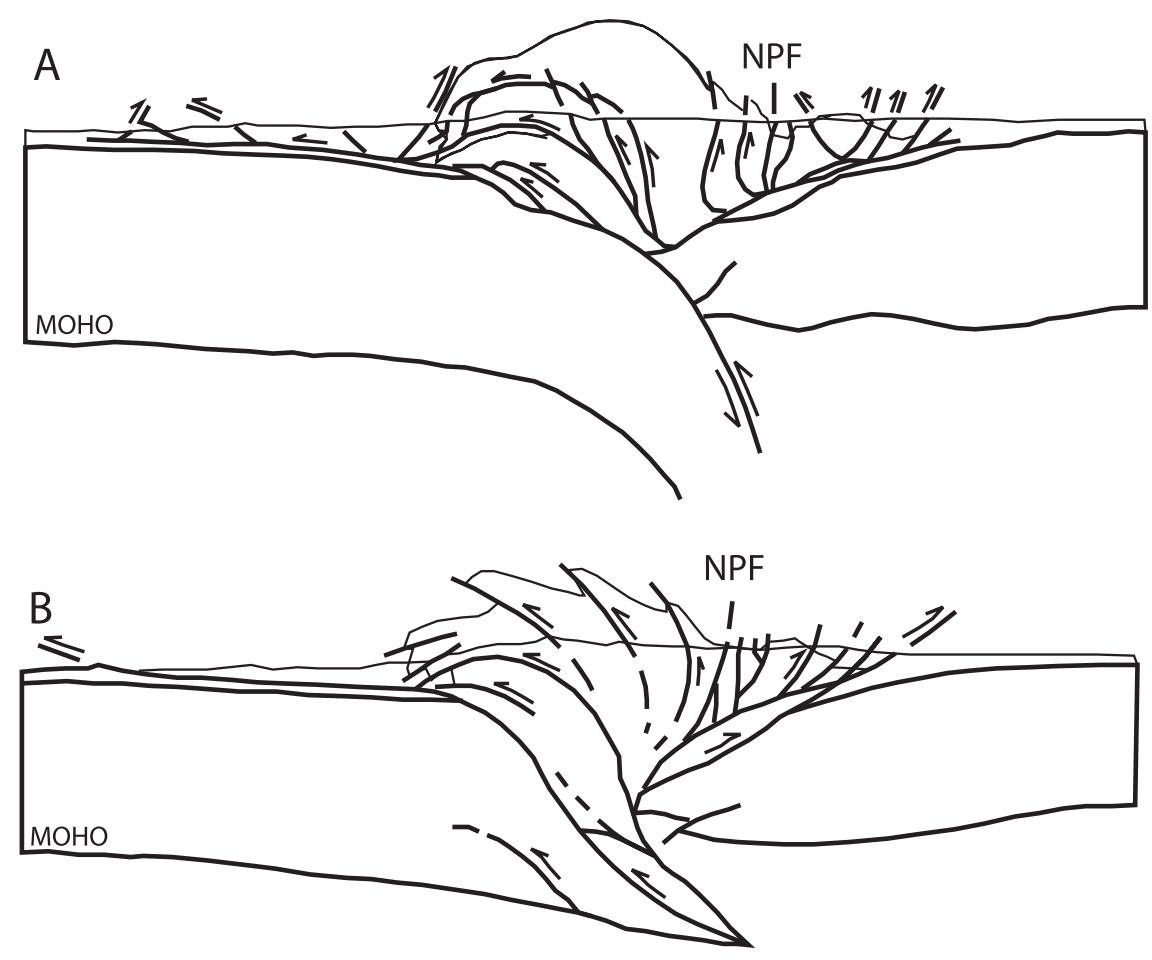

$0 \quad 50 \quad 100 \mathrm{~km}$

Figure 2. The two main interpretations of the ECORS-Pyrenees profile. (A) Model with subduction of Iberian lower crust, as proposed in Muñoz (1992). (B) Model with stacking of the Iberian crust beneath the Axial Zone, as proposed in Roure et al. (1989).

$S$

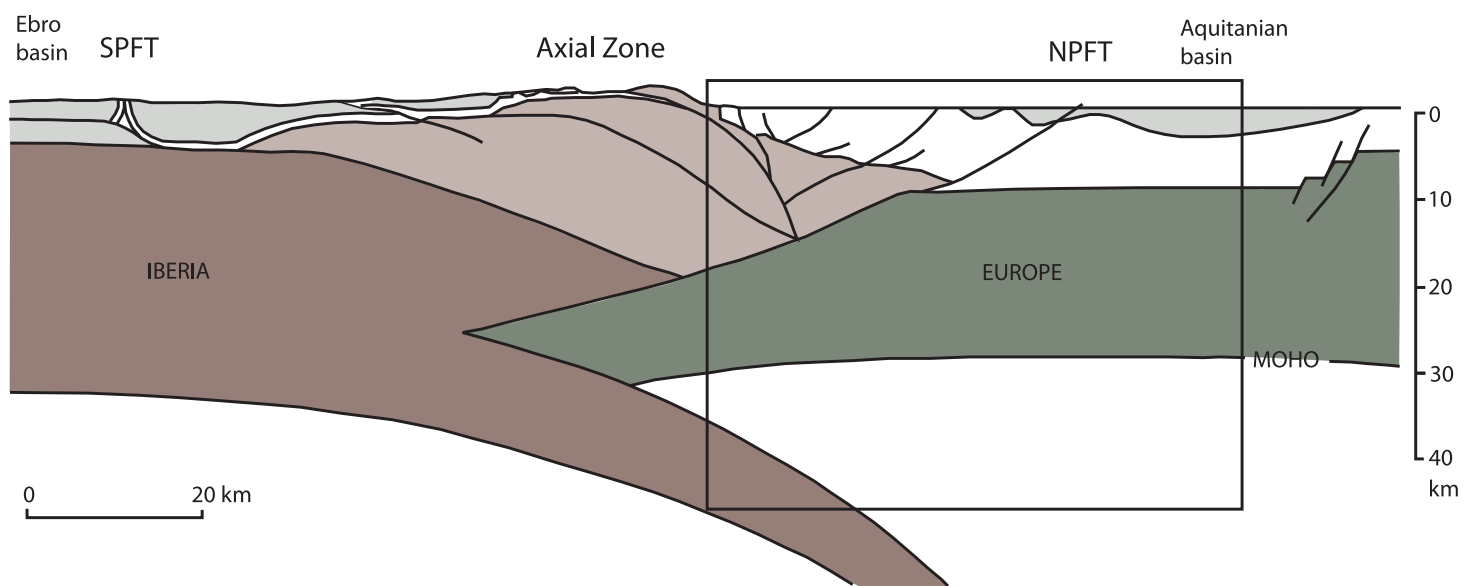

Figure 3. Interpretation of the ECORS-Arzacq profile (from Teixell 1998). Iberian crust materials are coloured in brown while European crustal materials are coloured in green. The grey and white units represent the Tertiary sediments. The black frame delimits the domain that was covered by the ECORS-Arzacq profile.

the Arzacq Basin to the north (Daignières et al. 1994). Beneath the Mendibelza Massif, the Iberian Moho is dipping towards the north. In contrast, the European Moho is approximately flat along the whole profile at a depth around $30 \mathrm{~km}$. These basic observations were later reinterpreted by Teixell (1998) as evidence for the deep indentation of the Iberian crust by the European crust, forming a double wedge beneath the axial zone (Fig. 3). Unfortunately, the ECORS-Arzacq profile did not extend sufficiently to the south to image this indentation. To balance the budget of crustal ma- terial, Teixell (1998) estimated that the Iberian lower crust must have been underthrusted to a minimum depth of at least $85 \mathrm{~km}$. Receiver function sections constructed from teleseismic data recorded by a small temporary array of six stations, complemented by the permanent stations in the western Pyrenees, were found consistent with the indentation of the Iberian and European crusts (Diaz et al. 2012). Another important finding of this study is that beneath the Basque Massifs area, west of the region sampled by the ECORSArzacq line, the Eurasian crust extends significantly farther south, 
confirming earlier results obtained from wide-angle seismic profiles (Pedreira et al. 2003).

Owing to the difficulty of illuminating deep seismic interfaces with active source experiments, but also because of the inherent ambiguity of deep reflector migration that is strongly dependent upon the velocity model, the different interpretations that have been proposed were all compatible with the main features seen in the ECORS sections. To get further insight into the deep architecture of the Pyrenees, two dense transects were successively deployed in the field between 2011 and 2013, during the temporary PYROPE experiment (Fig. 1). The sites of these two recording profiles were chosen as close as possible to the ECORS Pyrenees and Arzacq lines. However, the western profile has been significantly extended towards the south in order to cover the region where the Iberian crust is possibly indented by the European crust. In principle, owing to the broader frequency content and large amplitude of teleseismic waves that illuminate lithospheric structures from below, passive teleseismic imaging has a greater potential to image deep seismic interfaces compared to active source imaging. Combining the different geophysical surveys that probed the lithospheric architecture in the Pyrenees thus offers a rather unique opportunity to confront the results of active imaging with those of passive imaging.

Here we take advantage of teleseismic $P$ waves recorded by the two dense PYROPE transects in order to obtain a detailed image of seismic interfaces from the migration of $P$-to- $S$ converted phases. We first give a short overview of the PYROPE experiment and of the first results that were obtained. We then describe the preparation and selection of seismological data kept for the migration. Carefully selected examples of receiver function sections for the two profiles show clear indications of $\mathrm{N}-\mathrm{S}$ variations of the main seismic interfaces, in particular of the Moho. After describing the migration method, we present and discuss the results of migration. The new images reveal the geometry of Iberian and European Moho with great detail, and bring strong evidence for subduction of a thinned Iberian crust down to at least $70 \mathrm{~km}$ depth beneath both central and western Pyrenees.

\section{THE PYROPE AND IBERARRAY EXPER I M ENTS}

During the PYROPE experiment, a backbone of 50 temporary broad-band stations was deployed from 2010 October to 2013 October. The main scientific objective of this project was to obtain new high-resolution tomographic images of the deep architecture of the Pyrenees and Bay of Biscay. For this purpose, a crucial aspect of this project was the simultaneous deployment of the third leg of the IBERARRAY on the southern side of the Pyrenees, comprising about 70 temporary broad-band stations that were complementing the stations of the permanent French and Spanish networks. In addition to the 2-D backbone deployments, two dense profiles of temporary stations with wide-band Guralp CMG40 sensors have been deployed across the Pyrenees. The first profile, with its 37 stations installed from 2011 October to 2012 October in the central Pyrenees, approximately followed the ECORS Pyrenees line. The second western Pyrenees with 29 stations installed from 2012 October to 2013 October, followed a line going from Pamplona to Mont-de-Marsan. The interstation distance is comprised between 4 and $7 \mathrm{~km}$, with a denser coverage in the centre where crustal structures are expected to be more complex. A map of all the temporary and permanent stations in the study region that covers the Pyrenean range is shown in Fig. 1.
Regional tomography from the PYROPE and IBERARRAY data has already brought crucial insight into the lithospheric structures beneath the Pyrenees (Chevrot et al. 2014). This new tomographic model revealed the subduction of a segmented Iberian lithosphere beneath Europe, giving further support to the idea that the Pyrenees result from the tectonic inversion of a segmented rift that was buried by subduction beneath the European Plate. If this interpretation is correct, it implies that at least some fragments of the Iberian lithosphere have subducted beneath the European Plate. This would clearly favour models such as in Fig. 2(a) over those like in Fig. 2(b).

\section{DATA}

\subsection{Computation and selection of receiver functions}

At each station, we select all the $P$ records from events in a distance range between $30^{\circ}$ and $95^{\circ}$. The three components are cut from 50 s before to 250 s after the $P$ wave, and rotated to obtain vertical, radial and transverse components. The source time function for each event is estimated from the vertical component. This source time function is removed from the radial components, using the iterative deconvolution method of Ligorria \& Ammon (1999). The source normalized radial components, named receiver functions, are then filtered with a $2-\mathrm{Hz}$ gaussian filter. The receiver functions are then visually inspected to select only the good-quality traces. This screening process is performed on an event basis. It consists in forming for each event a section similar to those shown in Figs 5 and 6 and keeping only those traces that show coherent arrivals in the first $10 \mathrm{~s}$ after the $P$ wave. This criterion allows us to remove traces on which the $P$ waves have an apparent good $\mathrm{S} / \mathrm{N}$ ratio but for which only incoherent waves can be seen after the $P$ arrival. After selection, 504 traces were kept for the central transect and 513 traces for the western transect, from 20 different events in both cases. The azimuthal coverage for both transects is rather good, but limited by the absence of events in the Southern Hemisphere (Fig. 4). In this study, we will only focus on the radial receiver functions and leave the exploitation of transverse receiver functions for a future study focused on crustal anisotropy.

\subsection{Example 1: the 2012 May $24 M_{\mathrm{w}} 6.2$ Norwegian Sea earthquake}

During the 11 months field deployment of the first transect, a rare Norwegian Sea event occurred and was well recorded by all the stations. This earthquake is ideally located along the azimuth of the profile, at an epicentral distance around $30^{\circ}$. Fig. 5 shows the section of receiver functions for this event, where the records have been sorted as a function of distance along the profile. The origin of the distance axis is taken at the location of the southernmost station. On this section, the receiver functions have been aligned on the $P$ wave. Coherent signals are observed up to about $15 \mathrm{~s}$ after the $P$ wave. The Pms phase, which corresponds to the $P$-to- $S$ conversion on the Moho, is easily identified and can be followed along the whole profile (red dashed lines). This phase shows striking variations of its arrival time. It is recorded $5 \mathrm{~s}$ after the $P$ wave to the south of the profile and gets progressively delayed up to $7 \mathrm{~s}$ at a distance around $120 \mathrm{~km}$ beyond which it brutally jumps back to $5 \mathrm{~s}$. Interestingly, this brutal variation coincides with the position of the North Pyrenean Fault, below which wide-angle reflection profiles documented a 15-km Moho jump (Daignières et al. 1982). Other salient features are the phases with reverse polarity and increased 

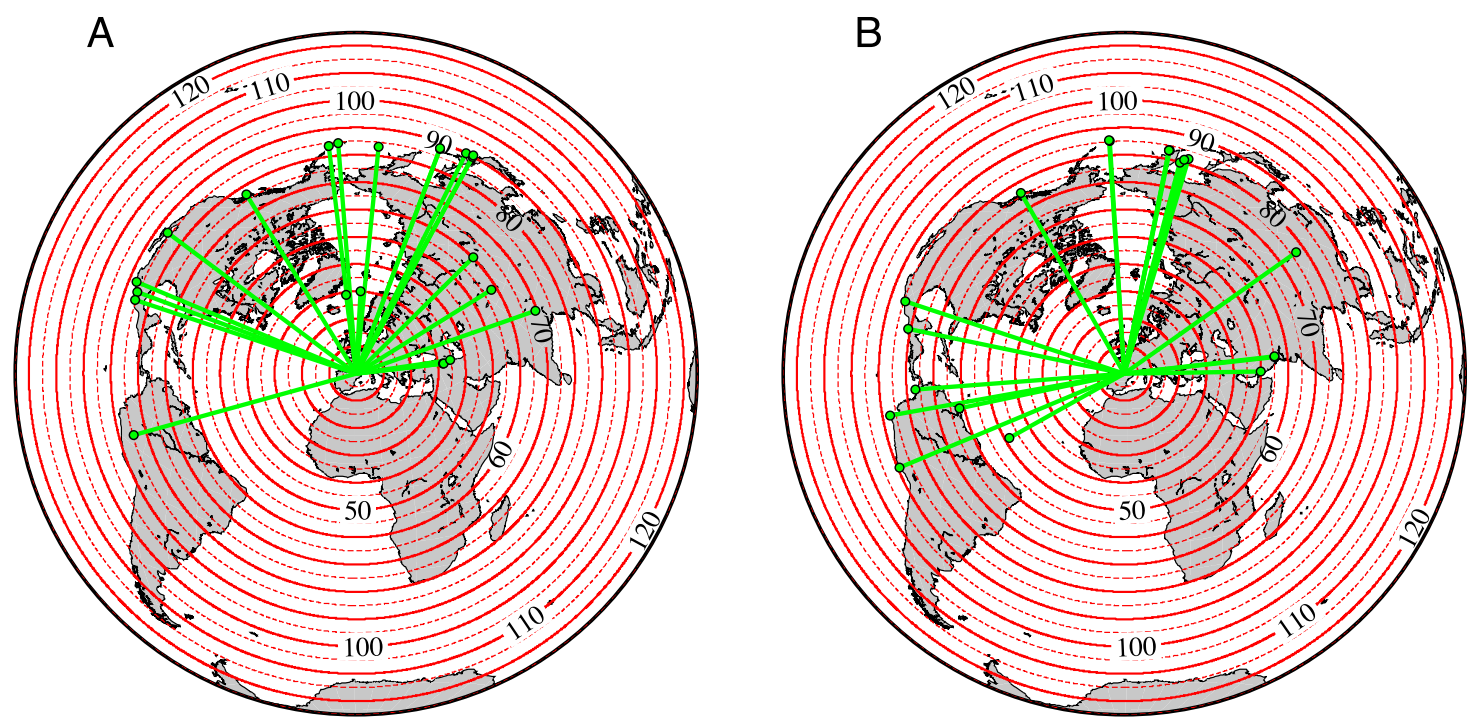

Figure 4. Azimuthal coverage to construct the CCP stacks for the central Pyrenees (A) and western Pyrenees (B) profiles.

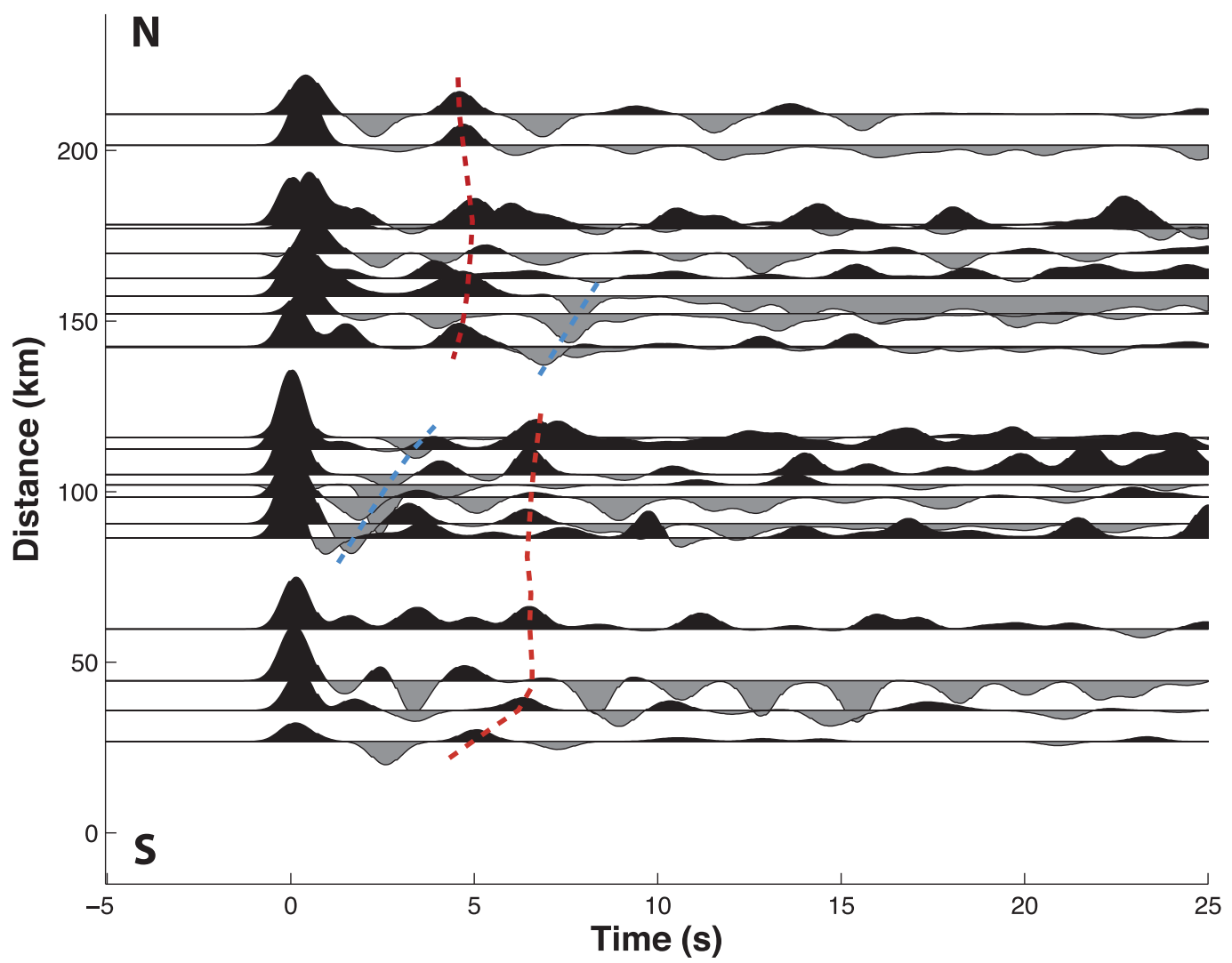

Figure 5. Radial receiver function section along the first Central Pyrenees profile for the 2012 May $24 M_{\mathrm{w}} 6.2$ Norwegian Sea earthquake. The receiver functions are aligned as a function of distance from the origin of the profile, taken at the position of the southernmost station. The origin time corresponds to the $P$-wave arrival.

delay time towards the north that are observed from 80 to $120 \mathrm{~km}$ and from 140 to $170 \mathrm{~km}$ distance (blue dashed lines).

\subsection{Example 2: the 2013 May $24 M_{\mathrm{w}}$ 8.3 Sea of Okhotsk earthquake}

The background noise level was generally high during the whole duration of the second deployment. This is probably because the second profile was closer to the main sources of microseismic noise close to the northern Galicia and Ireland coasts identified in Chevrot et al. (2007). The best event recorded during the deployment of the second profile occurred the same day as the Norwegian Sea event, but a year later. This is also an exceptional event for our purposes because it comes from a backazimuth that is close to the azimuth of the second profile. In addition, the $P$ waves generated by this strong and deep $M_{\mathrm{W}} 8.3$ event were in this case well above the background noise level. The RF section for this event is shown 


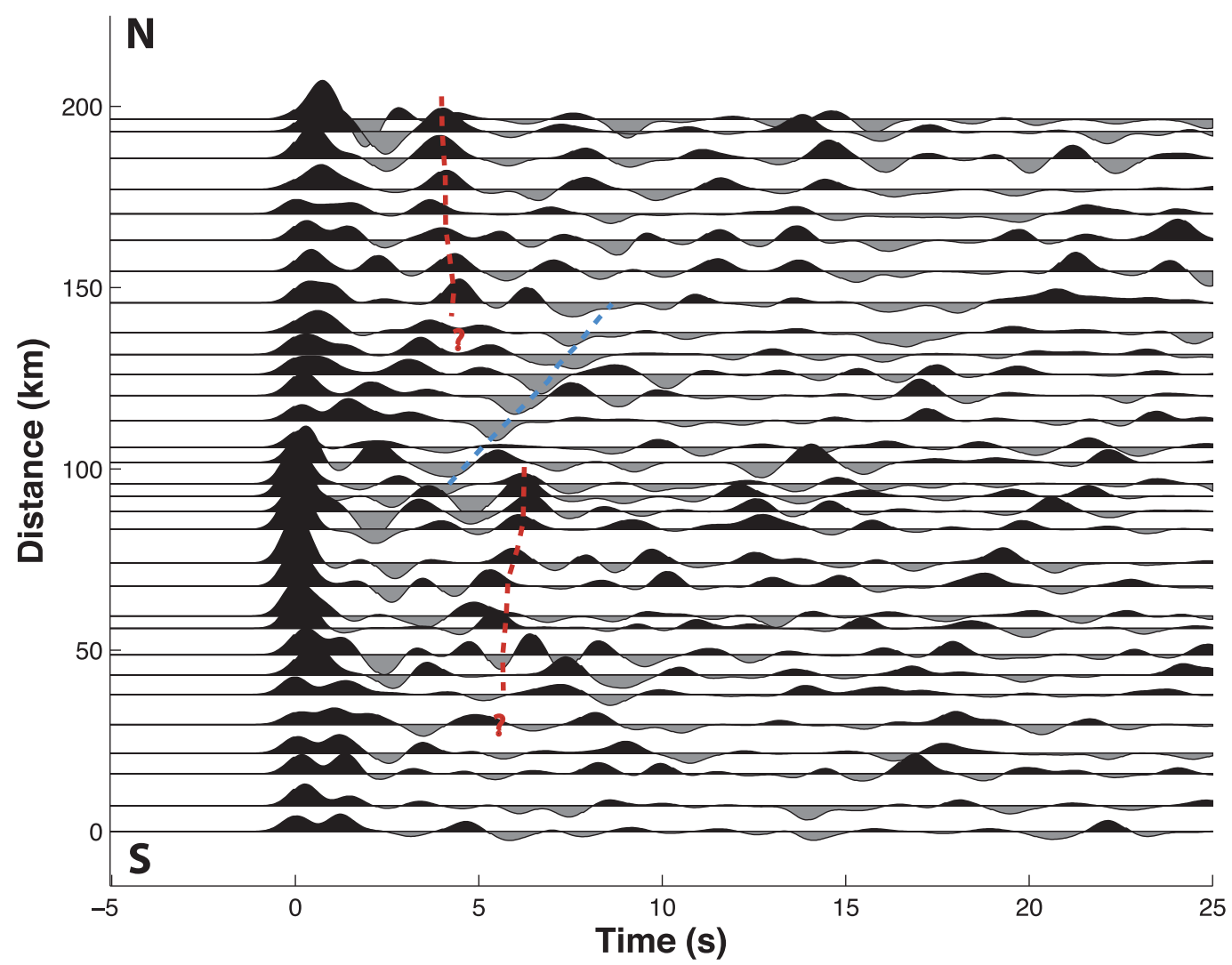

Figure 6. Radial receiver function section along the second Western Pyrenees profile for the 2013 May $24 M_{\mathrm{W}} 8.3$ Sea of Okhotsk earthquake. The receiver functions are aligned as a function of distance from the origin of the profile, taken at the position of the southernmost station. The origin time corresponds to the $P$-wave arrival.

in Fig. 6. This section also shows coherent arrivals up to $20 \mathrm{~s}$ after the $P$ wave, but with a much stronger variability than for the central profile. In particular, the $P$-to- $S$ conversions on the Moho (red dashed lines) are difficult to identify, especially in the south and in the centre of the profile. This is a clear indication of a stronger crustal heterogeneity. Another fundamental problem comes from the strong reverberations that can be clearly seen to the north of the profile at stations located beyond $130 \mathrm{~km}$ distance. These strong reverberations that form a regular and periodic sequence of arrivals with alternating polarities correspond to multiply reflected waves in the thick shallow sedimentary layers of the Aquitaine Basin. They interfere with the phases converted on deeper interfaces, in particular on the Moho, making its detection problematic. The most striking feature, as for the first profile, is an arrival with negative polarity that is observed in the middle of the profile between 3 and $8 \mathrm{~s}$ after the $P$ wave.

\section{MIGRATION OF TELESEISMIC $P$-TO- $S$ CONVERTED WAVES}

The simple analysis of the sections shown in Figs 5 and 6 has evidenced coherent $P S$ arrivals in the coda of teleseismic $P$ waves. We will now exploit these phases to map seismic interfaces in 2$\mathrm{D}$ vertical cross-sections beneath the two profiles. The principle is to transform the seismic records from the time domain to the depth domain. This transformation, called 'migration', is widely used in the processing of multichannel seismic reflection profiles. The main difference is that in our case we will exploit $P$-to- $S$ conversion on internal discontinuities, instead of $P-P$ reflections. The other main difference is that these converted waves are produced by the interaction between a teleseismic $P$ wave front emanating from a distant earthquake and the seismic discontinuities in the underlying medium. This passive imaging approach thus relies on the distribution and occurrence of natural earthquakes.

Different approaches can be used to migrate converted waves. The main difficulty is to separate the contribution of $P$-to- $S$ conversions from those of crustal multiples that will produce deep artefacts in the migrated section. While it has been demonstrated that including multiples in the imaging process improves the angular distribution of scattering, in particular in the backward direction, thus providing better images of the subsurface (Bostock et al. 2001; Pageot et al. 2013), because of their extra reflection beneath the free surface, those multiples are more sensitive to topography (Monteiller et al. 2013) and to crustal heterogeneity than primary conversions. As a result, if receiver functions have a sufficiently broad azimuthal and incidence angle distribution, a simple stack is usually sufficient to separate the coherent contribution of primary conversions. We decided to adopt this simple and yet powerful approach referred to as 'common conversion point' (CCP) stack (e.g. Zhu 2000) to get a quick first insight into the Pyrenean architecture from a data set of carefully chosen receiver functions.

The basic assumption of CCP stack (Zhu 2000) is that each time step on a receiver function after the $P$ arrival corresponds to the arrival of a $P$-to- $S$ conversion on a discontinuity at depth. Using the ak135 background velocity model (Kennett et al. 1995), with crustal velocities extended down to $60 \mathrm{~km}$ depth, we 
S
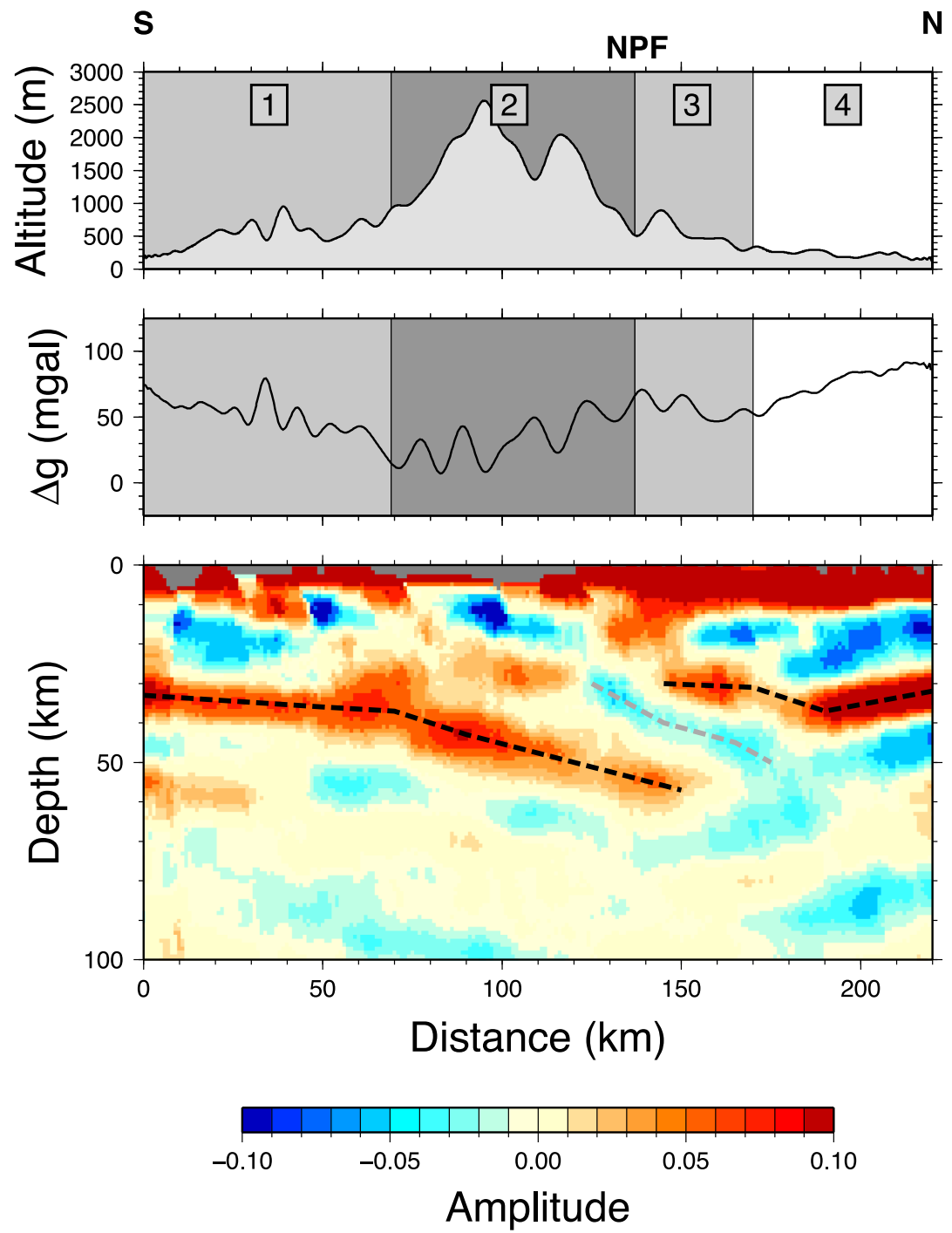

Figure 7. Topography (top panel) and Bouguer anomalies (middle panel) along the central transect. Bottom panel: CCP stack section for the central transect. The Moho, which corresponds to a positive downward velocity jump, appears in red while the top of the subducted Iberian crust appears in blue. The section crosses, from south to north, the South Pyrenean Zone (1), the Axial Zone (2), The North Pyrenean Zone (3) and the Aquitaine Basin (4). The North Pyrenean Fault corresponds to the limit at the surface between domains 2 and 3. The Iberian and European Moho are represented as black dashed lines and the top of the subducting Iberian crust as a grey dashed line.

backpropagate the ray paths downwards, starting from the locations obtained by projecting the stations on a linear profile. This linear profile is defined by the great circle that goes from the southernmost station, which corresponds to the origin of the profile, to the northernmost station. The medium is binned with $1 \mathrm{~km}$ square cells. We sum all the amplitudes that contribute to each individual bin and compute their average and variance. Horizontal smoothing is applied, using a smoothing length that increases with depth $z$ according to the Fresnel zone width $\sqrt{\lambda z}$, with wavelength $\lambda=4 \mathrm{~km}$. (which corresponds to an $S$ wavelength around $1 \mathrm{~s}$ period). For example, the smoothing length is $10 \mathrm{~km}$ at $20 \mathrm{~km}$ depth, and increases to $40 \mathrm{~km}$ at $40 \mathrm{~km}$ depth. Since this smoothing is also applied along the direction perpendicular to the profiles, this means that our images represent average 2-D structures over a corridor that is large enough to include all the contributions from off-line conversions.

\section{RESULTS}

\subsection{Central transect}

Fig. 7 shows the image obtained by migrating the $P$-to- $S$ conversions in the radial receiver functions with the CCP stacking technique. The red (blue) colours represent converted phases with positive (negative) amplitudes, generated on seismic interfaces corresponding to an increase (decrease) of shear velocity with depth. The Moho, which marks the limits between the crust (top) and mantle (bottom), should therefore appear in red. At the southern end of the profile, the Iberian Moho is clearly visible at a depth around $32 \mathrm{~km}$. It then dips gently towards the north to reach a depth of $37 \mathrm{~km}$ beneath the South Pyrenean Zone. Beneath the Axial Zone, the Moho is slightly deeper around $45 \mathrm{~km}$ depth. It is still gently dipping to the north beneath the North Pyrenean Zone. It can be followed down to $\sim 60 \mathrm{~km}$ depth, where the Moho velocity jump decreases abruptly. The 
determination of the exact depth penetration of the Iberian Moho is problematic because further north the migrated section is contaminated by strong reverberations occurring in the shallow sedimentary layers of the Aquitaine Basin. For the same reason, the detection of the European Moho in the northern part of the profile should be taken with caution. However, we note that its depth around $30 \mathrm{~km}$ at the northern end of the profile is in excellent agreement with the results of the ECORS-Pyrenees profile. Nevertheless, the CCP image clearly suggests a strongly north-dipping European Moho beneath the North Pyrenean Zone. Perhaps the most striking feature is the seismic interface that produces conversions with negative polarities that is observed from 120 to $190 \mathrm{~km}$ distance. It approximately parallels the Iberian Moho, but is shifted upwards by about $20 \mathrm{~km}$. A straightforward and natural interpretation of this seismic interface is that it corresponds to the contact between the European mantle on top and the Iberian crust beneath it. The last interpretable features in the image are the blue interfaces in the mid-crust of the Axial and South Pyrenean Zones. If not produced by waves multiply reflected on shallow discontinuities (as is presumably the case for those in the mid-crust of the North Pyrenean Zone and Aquitaine Basin) they would correspond to negative conversions on seismic interfaces that once again separate high-velocity materials located on top of slow velocity materials (i.e. thrust faults).

In general, the geometry and depth of the main seismic discontinuities seen in the CCP stack are in excellent agreement with the results of past seismic surveys. For example, the topographies of the Iberian and European Moho are very close to those seen in the ECORS Pyrenees line. The negative polarity interfaces in the mid-crust of the South Pyrenean Zone could correspond to Hercynian thrust faults as proposed by Choukroune et al. (1990) in its interpretation of the ECORS-Pyrenees profile. The two parallel north-dipping interfaces beneath the North Pyrenean Zone in the CCP image provide a direct and indisputable evidence for a continental subduction of Iberia beneath Europe in the central Pyrenees.

Variations of Bouguer anomalies follow different coherent trends inside the four structural domains that are crossed by the transect. In the South Pyrenean Zone, Bouguer anomalies decrease from $80 \mathrm{mGal}$ to $15 \mathrm{mGal}$. The growing mass deficit towards the north simply reflects the progressive deepening of the Iberian Moho. Beneath the Axial Zone, the Iberian Moho is still dipping towards the north but this time Bouguer anomalies increase, to reach a value of about $80 \mathrm{mGal}$ around the North Pyrenean Fault. This requires a rather strong positive anomaly at crustal levels, that is probably related to uplifted European lower crust or mantle material. Beneath the Aquitaine Basin, a simple pattern is again observed with the upward trend of Bouguer anomalies following the geometry of the European Moho.

\subsection{Western transect}

In spite of a larger microseismic noise level due to the proximity of the Atlantic Ocean and a much stronger complexity of the crust, the CCP stack for the western profile, shown in Fig. 8, displays a number of strong and coherent interfaces that can be interpreted. The Iberian Moho is barely detected beneath the South Pyrenean Zone, but the red coloured patterns suggest a ramp-like structure with a northward-dipping segment to the south followed by a rather flat segment further north. This weak Moho signature beneath the South Pyrenean Zone connects to a more strongly expressed northdipping interface located beneath the Axial Zone. This Iberian Moho can be followed down to at least $60 \mathrm{~km}$ depth. The European Moho is not clearly visible beneath the Axial Zone and starts to be detected beneath the North Pyrenean Zone, where it shows a flat geometry at a depth of around $25 \mathrm{~km}$. Further north, it plunges to reach a depth of $35 \mathrm{~km}$. Beneath the Aquitaine Basin, the Moho seems to be shallower, around $30 \mathrm{~km}$ depth, but this part of the image may again be contaminated by reverberations in the sedimentary layers. The most striking feature is, like in the image for the central profile, the interface that produces strong conversions with negative polarities observed from 60 to $180 \mathrm{~km}$ distance from the southern end of the profile. It is dipping to the north, going from 25 to $85 \mathrm{~km}$ depth. This interface also seems to be parallel to the Iberian Moho where it can be detected. The similarity with the image obtained on the central profile is striking, and gives further support to its interpretation as the top of the subducted Iberian crust. Another notable feature is the strong reduction of the velocity jump on the Iberian Moho below $60 \mathrm{~km}$, as observed in the other section. The main difference with the central profile is the interface with negative velocity jump observed between 10 and $20 \mathrm{~km}$ depth beneath the Axial Zone.

The comparison with the ECORS-Arzacq profile, which only covers the northern half of our western transect, reveals again compelling similarities. Indeed, the main results of the ECORS-Arzacq experiment regarding the deeper parts of the crust were to find an almost flat European Moho at $28.5 \mathrm{~km}$ depth that topped a deep northdipping interface, interpreted as the Iberian Moho by Daignières et al. (1994). This picture is in excellent agreement with the CCP stack, if the deep reflector is identified to the top of the underthrusted Iberian crust. Interestingly, our image is also in striking agreement with the interpretation of the ECORS profile shown in Fig. 3. Indeed, in order to explain the relative positions of the European and Iberian Moho, Teixell (1998) postulated that the Iberian crust is indented by the European crust, forming a characteristic 'crocodile' pattern. Such a crocodile pattern is clearly suggested by the two prominent negative (blue) discontinuities in the Axial Zone, with a position and geometry that match almost exactly Teixell's model.

For this transect, the variations of Bouguer anomalies (Fig. 8) also show simple patterns that can be directly related to the structures seen in the migrated section. Little variations of Bouguer anomalies are observed in the South Pyrenean Zone and in the Aquitaine Basin, where the Moho is almost flat. Bouguer anomalies increase progressively from $70 \mathrm{mGal}$ to $140 \mathrm{mGal}$ towards the north in the Labourd Massif (domain 2). This strong, positive anomaly, often referred to as the 'Labourd anomaly' coincides spatially with the 'crocodile' pattern. This would suggest that this anomaly is related to the mid-crustal indentation of the Iberian crust by the European crust. Beneath the North Pyrenean Zone, the Bouguer anomalies progressively decrease to reach a plateau around $100 \mathrm{mGal}$, following the sharp deepening of the European Moho towards the north.

\section{DISCUSSION}

\subsection{Implications of the CCP images for the structure and formation of the Pyrenees}

The first important conclusion of our study is that both profiles show clear evidence for subduction of the Iberian crust down to at least $\sim 60-70 \mathrm{~km}$ depth. Another important result is that this subducted Iberian crust is much thinner than a typical continental crust. Indeed, estimating the thickness of the subducted Iberian crust as the distance separating the black and grey dashed lines in Figs 7 and 8 , the apparent crustal thickness is only about $15 \mathrm{~km}$ to the west, while it is about $25 \mathrm{~km}$ in the central Pyrenees. This is consistent 
S
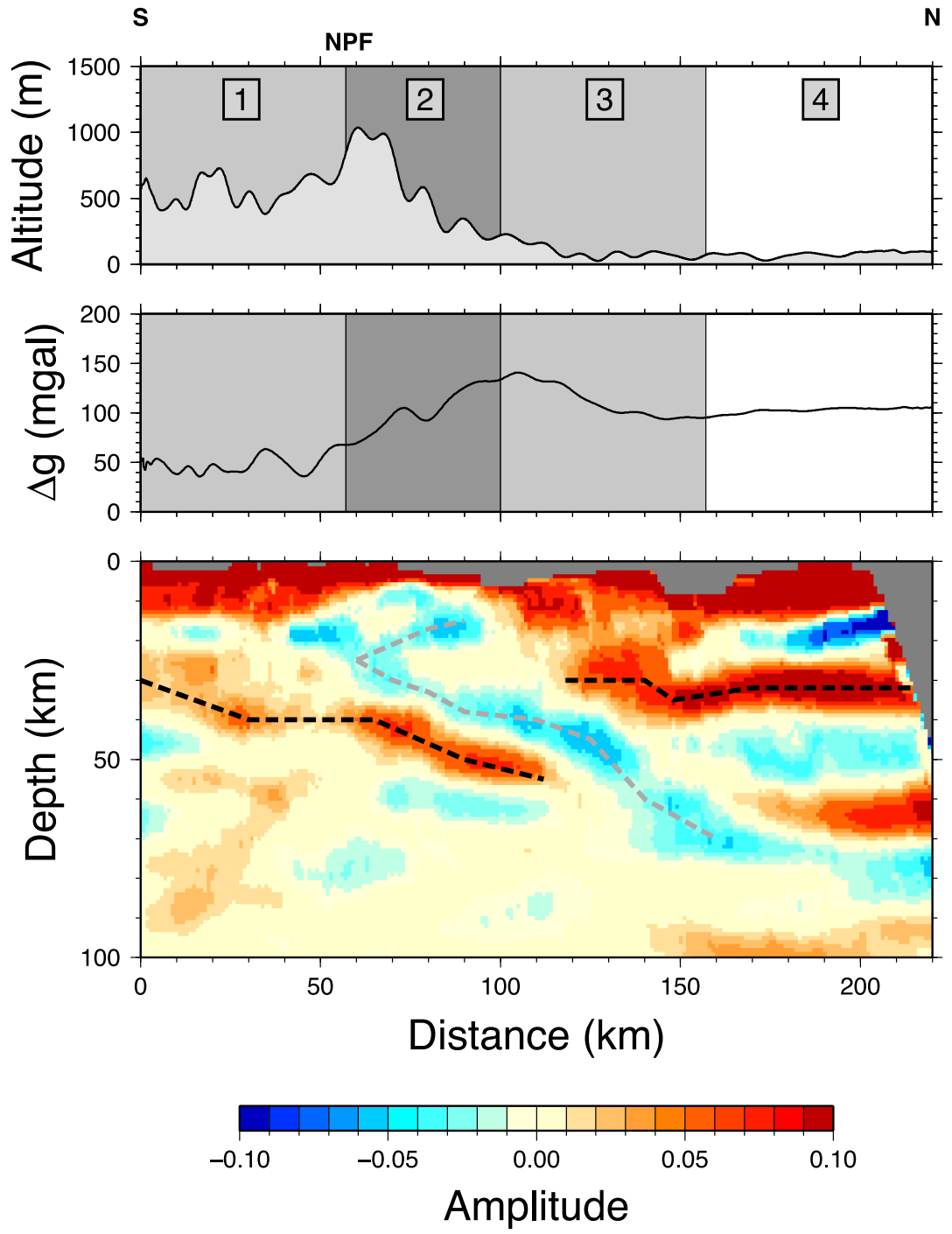

Figure 8. Topography (top panel) and Bouguer anomalies (middle panel) along the western transect. Bottom panel: CCP stack section for the western transect. The section crosses, from south to north, the South Pyrenean Zone (1), the Axial Zone (2), here corresponding to the Labourd Massif, the North Pyrenean Zone (3), here corresponding to the Mauleon Basin and the Aquitaine Basin (4). The North Pyrenean Fault corresponds to the limit at the surface between domains 1 and 2. The Iberian and European Moho are represented as black dashed line. The top of the subducting Iberian crust from 30 to $70 \mathrm{~km}$ depth is represented as a grey dashed line. We also represent as a grey dashed line the thrust plane that corresponds to the top 'jaw' of the 'crocodile'.

with the growing geological evidences that the Iberian crust north of the Axial Zone was already thinned in Campanian/Santonian, before the onset of continental subduction (e.g. Lagabrielle \& Bodinier 2008; Jammes et al. 2009; Lagabrielle \& de Saint Blanquat 2010; Clerc et al. 2012; Tugend et al. 2014). The different and more pronounced crustal thinning to the west could result from rift segmentation, the western and central Pyrenees belonging to two distinct rift segments. Another striking difference is the 'crocodile' pattern observed in the western Pyrenees. Recent analogue experiments aimed at characterizing the influence of lateral variations in lithosphere rheology on subduction polarity produced similar structures in the transition region where polarity reversal of subduction occurs (Midtkandal et al. 2013). By analogy, applying these results to the Cantabrian-Pyrenean orogen, these authors suggest that the crocodile pattern could thus result from the interference between a north-dipping subduction beneath the Pyrenees and a south-dipping subduction beneath the Bay of Biscay.

These results have already some important implications for the present architecture of the Pyrenean lithosphere. A common view is that the NPF played a major role in the structuration of the Pyrenees. According to this model, the NPF was a major subvertical transform plate boundary that accommodated the left-lateral motion of Iberia with respect to Europe during the Cretaceous, with little later Alpine convergence (e.g. Choukroune \& Mattauer 1978; Roure \& Choukroune 1998). This view is again incompatible with the significant amount of subducted Iberian crust evidenced in our migration images, which undermines the importance previously attributed to the NPF. In contrast, our images give further support to the idea that the Pyrenees result from the tectonic inversion of a segmented hyperextended rift that was underthrusted beneath the European Plate.

Another important question is the nature of the subducted crustal material. A puzzling observation that can be made on both migrated sections is the disappearance of the Iberian Moho beneath $60 \mathrm{~km}$ depth. A simple explanation would be to invoke a phase transition with an eclogitization of the crust below that depth. However, since the shear velocities of peridotites and eclogites are very similar (Worthington et al. 2013), a subducted eclogitized Iberian crust is 
hard to reconcile with the rather strong downward negative shear velocity gradient along the hypothesized top of the Iberian crust down to at least $80 \mathrm{~km}$ depth on the western section. However, eclogitization of the subducted Iberian crust cannot be excluded since the downward velocity decrease at the top of the Iberian crust could result from partial melting of the upper crust, as proposed in Campanyà et al. (2011) and Campanyà et al. (2012) to explain the low resistivities observed in two central and western magnetotelluric profiles, or from a faster harzburgitic European lithospheric mantle. These different hypotheses are not mutually exclusive and could be easily discriminated from the density and seismic velocity anomalies in the Pyrenean lithosphere. The regional tomographic model recently obtained from the exploitation of the data of the PYROPE and IBERARRAY temporary experiments (Chevrot et al. 2014) gives us some first-order constraints on the distribution of compressional velocities in the lithosphere. In this model, the European lithosphere is faster than average beneath the two profiles, which would be consistent with an harzburgitic composition. On the other hand, the serpentinisation of the Iberian crust would provide a simple alternative explanation for both the disparition of Moho at depth and for the signature of the Iberian crust/European mantle interface in the migrated sections. Indeed, in hyperextended margins, it is common to observe a gradual transition between crust and mantle resulting from the serpentinisation of the lithosphere, with no visible signature of the Moho in seismic reflection data (e.g Minshull 2009).

The last striking feature in the migrated western section is the weakly expressed Iberian Moho at the southern end of the profile (distances between 0 and $50 \mathrm{~km}$ ), which suggests a weak or gradual velocity gradient, in good agreement with the results of the ambient noise tomography by Macquet et al. (2014). Interestingly, the regional tomographic model by Chevrot et al. (2014) shows low $P$ velocities in the Iberian lithosphere in this region. The along-strike geometry of this low-velocity anomaly and its southern location with respect to the Pyrenean range would suggest that it corresponds to the remnants of the Albian rift, the Iberian Plate having moved northwards during the later convergence phase. If this interpretation is correct, it would favour a thermal origin for this anomaly, resulting from metasomatism and heating of the Iberian lithosphere by the hot subrift asthenospheric mantle. This could explain the small downward velocity gradient in the southern part of the western profile.

At this point, going further into the interpretations will require 3-D images of density and seismic velocities with a much finer resolution than in current regional tomographic models.

\subsection{Active versus passive internal discontinuity imaging}

The comparison between active and passive imaging clearly demonstrates that the latter brings additional important informations that could not be obtained with the former, in particular regarding the deep lithospheric interfaces that are difficult to illuminate with active experiments owing to the limited power of explosive sources. Another advantage of the imaging approach based upon conversions over conventional deep seismic reflection profiles is that the sign of the velocity jumps on internal discontinuities is easily characterized. This provides important guidelines for structural interpretation. The main drawback of passive imaging is that it is extremely difficult to characterize the upper crust with this approach, because $P$-to- $S$ conversions on shallow discontinuities are too close to the direct $P$ wave. In contrast, seismic reflection data, thanks to their higher frequency content, allow precise and accurate characterization of shallow reflectors, that can often be correlated to well logs data in order to precise the nature and composition of the main crustal units. Another fundamental limitation of passive imaging stems from the strong reverberations in shallow sedimentary layers that will mask conversions on deeper discontinuities such as the Moho. Since mountain ranges are typically surrounded by foreland basins, this problem is often met in practice. A possible remedy would be to consider $S p$ conversions, which arrive before the $S$ wave, and which are not contaminated by the later arrivals of such multiply reflected waves. This strategy has been followed for example by Hansen et al. (2009) to estimate the Moho depth beneath the Transantarctic Mountains and East Antarctic Craton, to avoid the contamination of conversions and multiples generated on the ice-rock interface. To summarize, passive and active imaging have both advantages and shortcomings and complement each other. The ideal case is to have access to both sources of information, as in the Pyrenees, which provides unique opportunities to improve our understanding of the formation and evolution of mountain ranges.

\subsection{Limitations of CCP stack and future work}

It is important to stress the limitations of the CCP stack approach. First, the migration is performed in a 1-D background model, here the ak135 reference model. Neglecting the strong lateral variations of seismic velocities that are present in our study region will inevitably lead to distortions in the recovered geometry of seismic interface. In addition, CCP stacks rely on the implicit assumption that wave conversions occur on subhorizontal discontinuities. While this algorithm is still able to detect dipping interfaces, as testified by the coherent inclined interfaces observed in the two migrated sections, their dip is likely to be significantly biased. This bias increases with the dip angle, and usually leads to underestimate the dip of the inclined interface (Schneider et al. 2013). These artefacts are expected to be strongly attenuated in 3-D Kirchhoff migration (Bostock et al. 2001; Rondenay 2009), but it is likely that using more sophisticated migration techniques would not change the results of migration to the point of revising the structural interpretation. As already pointed out, the next progresses will come from very finely resolved tomographic images of both $P$ and $S$ velocities. Such a breakthrough will require to move from asymptotic migration and tomographic methods towards full waveform inversion of the complete wavefield. The development of such a new imaging method is currently under way.

\section{CONCLUSIONS}

Using the teleseismic $P$ waves recorded by two dense transects deployed in the central and western Pyrenees, we migrated the $P$-to$S$ converted waves to map the seismic interfaces beneath these two transects. The sign of the velocity jump is readily observable in the migration images exploiting $P$-to- $S$ conversions while it is usually unclear in seismic reflection sections. This information provides precious guidelines for structural interpretation. More importantly, passive imaging from conversions allows us to see much deeper seismic interfaces that cannot be illuminated with deep seismic sounding, owing to power limitations of active sources. As a result, migrated sections reveal details of the deep lithospheric architecture that could not be seen in the ECORS seismic surveys.

Our migration images allowed us to map the geometry of the Iberian and European Moho, that are clearly disconnected. The 
disconnection, associated to a strong Moho offset, approximately coincides with the position of the North Pyrenean Fault in the first profile (the limit between domains 2 and 3 in Fig. 7), in excellent agreement with past deep seismic surveys. To the west, a similar Moho offset is observed but it is found beneath the North Pyrenean Zone, $60 \mathrm{~km}$ north from the surface trace of the North Pyrenean Fault. Our images provide compelling evidence for the subduction of a thinned Iberian crust down to at least $\sim 70 \mathrm{~km}$ depth. The 'crocodile' pattern observed in the crust is in remarkable agreement with the interpretation of the ECORS-Arzacq profile proposed by Teixell (1998). The subducted crust is apparently thinner in the west than in the central Pyrenees, which would suggest that the Albian extension in the Pyrenean domain was more important to the west. This result is consistent with a rift opening orthogonally to the Pyrenees, segmented by major transfer faults such as the Pamplona and Toulouse faults, as proposed by Jammes et al. (2009). Our study gives further support to the idea that the Pyrenees were formed by subduction of a segmented rift beneath the European Plate.

\section{ACKNOWLEDGEMENTS}

The PYROPE experiment was supported by the French Research Agency ANR blanc programme (project PYROPE, ANR-09BLAN-0229). We also acknowledge SISMOB, the French seismic mobile pool (a component of the RESIF consortium), for providing us with the seismological instrumentation for the temporary deployments. RESIF (http://portal.resif.fr/) is a national Research Infrastructure, recognized as such by the French Ministry of Higher Education and Research. RESIF is managed by the RESIF Consortium, composed of 18 Research Institutions and Universities in France. RESIF additionally supported by a public grant overseen by the French National Research Agency (ANR) as part of the 'Investissements d'Avenir' programme (reference: ANR-11-EQPX-0040) and the French Ministry of Ecology, Sustainable Development and Energy.

\section{REFERENCES}

Beaumont, C., Muñoz, J.A., Hamilton, J. \& Fullsak, P., 2000. Factors controlling the Alpine evolution of the central Pyrenees inferred from a comparison of observations and geodynamical models, J. geophys. Res., 105, 8121-8145.

Bostock, M.G., Rondenay, S. \& Shragge, J., 2001. Multiparameter twodimensional inversion of scattered teleseismic body waves, 1 . Theory for oblique incidence, J. geophys. Res., 106, 30 771-30 782.

Brunet, M.F., 1986. The influence of the evolution of the Pyrenees on adjacent basins, Tectonophysics, 129, 343-354.

Campanyà, J., Ledo, J., Queralt, P., Marcuello, A., Liesa, M. \& Muñoz, J.A., 2011. Lithospheric characterization of the central pyrenees based on new magnetotelluric data, Terra Nova, 23, 213-219.

Campanyà, J., Ledo, J., Queralt, P., Marcuello, A., Liesa, M. \& Muñoz, J.A., 2012. New geoelectrical characterisation of a continental collision zone in the West-Central Pyrenees: constraints from long-period and broadband magnetotellurics, Earth planet. Sci. Lett., 333-334, 112-121.

Casas, A., Kearey, P., Rivero, L. \& Adam, C.R., 1997. Gravity anomaly map of the Pyrenean region and a comparison of the deep geological structure of the western and eastern Pyrenees, Earth planet. Sci. Lett., 150, 65-78.

Chevrot, S., Sylvander, M., Ponsolles, C., Benahmed, S., Lefèvre, J.M. \& Paradis, D., 2007. Source locations of secondary microseisms in western Europe: evidence for both coastal and pelagic sources, J. geophys. Res., 112, B11301, doi:10.1029/2007JB005059.

Chevrot, S., Villaseñor, A., Sylvander, M. \& The Pyrope Team 2014. High resolution imaging of the Pyrenees and Massif Central from the data of the PYROPE and IBERARRAY portable array deployments, J. geophys. Res., 119, 6399-6420.

Choukroune, P. \& The ECORS Team 1989. The ECORS pyrenean deep seismic profile reflection data and the overall structure of an orogenic belt, Tectonics, 8, 23-39.

Choukroune, P. \& Mattauer, M., 1978. Tectonique des plaques et Pyrénées: sur le fonctionnement de la faille transformante nord-pyrénéenne; comparaison avec des modèles actuels, Bull. Soc. géol. France, 7, 689-700.

Choukroune, P., Pinet, B., Roure, F. \& Cazes, M., 1990. Major Hercynian thrusts along the ECORS Pyrenees and Biscay lines, Bull. Soc. géol. France, 2, 313-320.

Clerc, C., Lagabrielle, Y., Neumaier, M., Reynaud, J.Y. \& de Saint Blanquet, M., 2012. Exhumation of subcontinental mantle rocks: evidence from ultramafic-bearing clastic deposits nearby the Lherz peridotite body, French Pyrenees, Bull. Soc. géol. France, 183, 443-459.

Daignières, M., Gallart, J. \& Banda, E., 1981. Lateral variation of the crust in the North-Pyrenean zone, Ann. Geophys., 37, 435-456.

Daignières, M., Gallart, J., Banda, E. \& Hirn, A., 1982. Implications of the seismic structure for the orogenic evolution of the Pyrenean range, Earth planet. Sci. Lett., 57, 88-100.

Daignières, M., de Cabissole, B., Gallart, J., Hirn, A., Surinach, E. \& Torne, E., 1989. Geophysical constraints on the deep structure along the ECORS Pyrenees line, Tectonics, 8, 1051-1058.

Daignières, M., Séguret, M., Specht, M. \& ECORS Team, 1994. The ArzacqWestern Pyrenees ECORS deep seismic profile, in Hydrocarbon and Petroleum Geology of France, ed. Mascle, A., Springer-Verlag.

Diaz, J., Pedreira, D., Ruiz, M., Pulgar, J.A. \& Gallart, J., 2012. Mapping the indentation between the Iberian and Eurasian plates beneath the Western Pyrenees/Eastern Cantabrian Mountains from receiver function analysis, Tectonophysics, 570-571, 114-122.

ECORS Pyrenees Team, 1988. The ECORS deep reflection seismic survey across the Pyrenees, Nature, 331, 508-511.

Explosion Seismology Group Pyrenees, 1980. Seismic reconnaissance of the Pyrenees, Ann. Geophys., 36, 135-140.

Gallart, J., Banda, E. \& Daignières, M., 1981. Crustal structure of the Paleozoic axial-zone of the Pyrenees and transition to the North-Pyrenean zone, Ann. Geophys., 37, 457-480.

Hansen, S.E., JuliàJ. Nyblade, A.A., Pyle, M.L., Wiens, D.A. \& Anandkrishnan, S., 2009. Using $S$ wave receiver functions to estimate crustal structure beneath ice sheets: an application to the transantarctic mountains and east antarctic craton, Geochem. Geophys. Geosyst., 10, Q08014, doi:10.1029/2009GC002576.

Jammes, S., Manatschal, G., Lavier, L. \& Masini, E., 2009. Tectonosedimentary evolution related to extreme crustal thinning ahead of a propagating ocean: example of the western Pyrenees, Tectonics, 28, TC4012, doi:10.1029/2008TC002406.

Kennett, B.L.N., Engdahl, E.R. \& Buland, R., 1995. Constraints on seismic velocities in the Earth from traveltimes, Geophys. J. Int., 122, 108-124.

Lagabrielle, Y. \& Bodinier, J.L., 2008. Submarine reworking of exhumed subcontinental mantle rocks: field evidence from the Lherz peridotites, French Pyrenees, Terra Nova, 20, 11-21.

Lagabrielle, Y., Labaume, P. \& de Saint Blanquat, M., 2010. Mantle exhumation, crustal denudation, and gravity tectonics during Cretaceous rifting in the Pyrenean realm (SW Europe): insights from the geological setting of the lherzolite bodies, Tectonics, 29, TC4012, doi:10.1029/2009TC002588.

Ligorria, J.P. \& Ammon, C.J., 1999. Iterative deconvolution and receiverfunction estimation, Bull. seism. Soc. Am., 89, 1395-1400.

Macquet, M., Paul, A., Pedersen, H.A., Villaseñor, A., Chevrot, S., Sylvander, M., Wolyniec, D. \& PYROPE Working Group, 2014. Ambient noise tomography of the Pyrenees and surrounding regions: inversion for a 3-D Vs model in the presence of a very heterogeneous crust, Geophys. J. Int., 199, 402-415.

Midtkandal, I., Brun, J.P., Gabrielsen, R.H. \& Huismans, R.S., 2013. Control of lithosphere rheology on subduction polarity at initiation: insights from 3D analogue modelling, Earth planet. Sci. Lett., 361, 219-228.

Minshull, T.A., 2009. Geophysical characterisation of the ocean-continent transition at magma-poor rifted margins, C. R. Geoscience, 341, 382-393. 
Monteiller, V., Chevrot, S., Komatitsch, D. \& Fuji, N., 2013. A hybrid method to compute short-period synthetic seismograms of teleseismic body waves in a 3-D regional model, Geophys. J. Int., 192, 230-247.

Muñoz, J.A., 1992. Evolution of a continental collision belt: ECORSPyrenees crustal balanced cross-section, in Thrust Tectonics, pp. 235-246, ed. McClay, K.R., Chapman \& Hall.

Olivet, J.L., 1996. La cinématique de la plaque Ibérique, Bulletin des Centres de Recherches Exploration-Production Elf-Aquitaine, 20, 131-195.

Pageot, D., Operto, S., Vallée, M., Brossier, R. \& Virieux, J., 2013. A parametric analysis of two-dimensional elastic full waveform inversion of teleseismic data for lithospheric imaging, Geophys. J. Int., 193, 14791505.

Pedreira, D., Pulgar, J.A., Gallart, J. \& Diaz, J., 2003. Seismic evidence of Alpine crustal thickening and wedging from the western Pyrenees to the Cantabrian Mountains (north Iberia), J. geophys. Res., 108, doi:10.1029/2001JB001667.

Rondenay, S., 2009. Upper mantle imaging with array recordings of converted and scattered teleseismic waves, Surv. Geophys., 30, 377-405.

Roure, F. \& Choukroune, P., 1998. Contribution of the ECORS seismic data to the Pyrenean geology: crustal architecture and geodynamic evolution of the Pyrenees, Mém. Soc. géol. France, 173, 37-52.

Roure, F. et al., 1989. ECORS deep seismic data and balanced cross sections: geometric constraints on the evolution of the Pyrenees, Tectonics, $\mathbf{8}$, 41-50.
Schneider, F.M. et al., 2013. Seismic imaging of subducting continental lower crust beneath the Pamir, Earth planet. Sci. Lett., 375, 101-112.

Suriñach, E., Marthelot, J.M., Gallart, J., Daignières, M. \& Hirn, A., 1993. Seismic images and evolution of the Iberian crust in the Pyrenees, Tectonophysics, 221, 67-80.

Teixell, A., 1998. Crustal structure and orogenic material budget in the west central Pyrenees, Tectonics, 3, 395-406.

Torné, M., De Cabissole, B., Bayer, R., Casas, A., Daignières, M. \& Rivero, A., 1989. Gravity constraints on the deep structure of the pyrenean belt along the ECORS profile, Tectonophysics, 165, 105-116.

Tugend, J., Manatschal, G., Kusznir, N.J., Masini, E., Mohn, G. \& Thinon, I., 2014. Formation and deformation of hyperextended rift systems: insights from rift domain mapping in the Bay of Biscay-Pyrenees, Tectonics, 33, 1239-1276.

Vacher, P. \& Souriau, A., 2001. A 3-D model of the Pyrenean deep structure based on gravity modelling, seismic images, and petrological constraints, Geophys. J. Int., 145, 460-470.

Worthington, J.R., Hacker, B.R. \& Zandt, G., 2013. Distinguishing eclogite from peridotite: EBSD-based calculations of seismic velocities, Geophys. J. Int., 193, 489-505.

Zhu, L., 2000. Crustal structure across the San Andreas Fault, southern California from teleseismic converted waves, Earth Planet. Sci. Lett., 179, 183-190. 